\title{
Moving Beyond Global Warming Potentials to Quantify the Climatic Role of Ecosystems
}

\author{
Scott C. Neubauer ${ }^{1 *}$ and J. Patrick Megonigal ${ }^{2}$ \\ ${ }^{1}$ Department of Biology, Virginia Commonwealth University, 1000 West Cary Street, Richmond, Virginia 23284, USA; ${ }^{2}$ Smithsonian \\ Environmental Research Center, P.O. Box 28, Edgewater, Maryland 21037, USA
}

\begin{abstract}
For decades, ecosystem scientists have used global warming potentials (GWPs) to compare the radiative forcing of various greenhouse gases to determine if ecosystems have a net warming or cooling effect on climate. On a conceptual basis, the continued use of GWPs by the ecological community may be untenable because the use of GWPs requires the implicit assumption that greenhouse gas emissions occur as a single pulse; this assumption is rarely justified in ecosystem studies. We present two alternate metrics-the sustained-flux global warming potential (SGWP, for gas emissions) and the sustained-flux global cooling potential (SGCP, for gas uptake)-for use when gas fluxes persist over time. The SGWP is generally larger than the GWP (by up to $\sim 40 \%$ ) for both methane and nitrous oxide emissions, creating situations where the GWP and SGWP metrics could provide opposing interpretations about the climatic role of an ecosystem. Further, there is an asymmetry in methane and nitrous oxide dynamics between persistent emission and uptake situations, producing
\end{abstract}

very different values for the SGWP vs. SGCP and leading to the conclusion that ecosystems that take up these gases are very effective at reducing radiative forcing. Although the new metrics are more realistic than the GWP for ecosystem fluxes, we further argue that even these metrics may be insufficient in the context of trying to understand the lifetime climatic role of an ecosystem. A dynamic modeling approach that has the flexibility to account for temporally variable rates of greenhouse gas exchange, and is not limited by a fixed time frame, may be more informative than the SGWP, SGCP, or GWP. Ultimately, we hope this article will stimulate discussion within the ecosystem science community about the most appropriate way(s) of assessing the role of ecosystems as regulators of global climate.

Key words: biogeochemical cycling; atmospheric perturbation model; climate change; carbon sequestration; radiative forcing; switchover time; carbon dioxide; methane; nitrous oxide.
Received 6 January 2015; accepted 15 March 2015; published online 16 May 2015

Author contributions SCN designed the study, developed and ran the model, and analyzed the data. JPM provided input on data interpretation/ presentation. Both SCN and JPM wrote and edited the manuscript. *Corresponding author; e-mail: sneubauer@vcu.edu

\section{INTRODUCTION}

Ecosystems are a fundamental component of the earth system that must be understood in order to model and manage atmospheric greenhouse gas concentrations and therefore global climate. Carbon dioxide $\left(\mathrm{CO}_{2}\right)$ removed from the atmosphere by primary producers can be stored for decades to thousands of years in woody biomass and soil 
organic matter (Torn and others 1997; Gough and others 2008; Hakkenberg and others 2008). Further, ecosystems either add or remove the greenhouse gases methane $\left(\mathrm{CH}_{4}\right)$ and nitrous oxide $\left(\mathrm{N}_{2} \mathrm{O}\right)$ from the atmosphere (Syakila and Kroeze 2011; Serrano-Silva and others 2014), which can either offset (gas additions) or reinforce (gas removals) the climatic benefits of carbon sequestration. Each greenhouse gas differs in its atmospheric lifetime and radiative efficiency (that is, how effectively a gas absorbs and re-radiates infrared radiation). The global warming potential (GWP) is the most commonly used metric for comparing the relative radiative forcing of gases with different lifetimes, radiative characteristics, and cycling. Using the GWP, greenhouse gas fluxes are converted to a common unit- $\mathrm{CO}_{2}$ equivalents-and then compared directly to one another to determine whether an ecosystem has a net warming or cooling effect on global climate. This approach of using GWPs to examine greenhouse gas balances has been used in the ecological community for over two decades (for example, Gorham 1991; Robertson and others 2000; Whiting and Chanton 2001; Shrestha and others 2009; Poffenbarger and others 2011; van Groenigen and others 2011; Weston and others 2014). Far less common in the ecological community is the approach of directly modeling the atmospheric dynamics of greenhouse gases (Frolking and others 2006; Frolking and Roulet 2007; Neubauer 2014).

By definition, the GWP is "the time-integrated radiative forcing due to a pulse emission of a given component, relative to a pulse emission of an equal mass of $\mathrm{CO}_{2}{ }^{\prime \prime}$ (Sect. 8.7.1.2 of Myhre and others 2013a). This definition contains several important points. Firstly, the GWP is a time-integrated index and thus its value changes depending on the time scale of interest. Because ecosystem ecologists are generally interested in the effects of a change in emissions on near-term climate change, most greenhouse gas source/sink calculations use a 100year time frame. However, it should be noted that all time scales are arbitrary, and both shorter and longer time scales are reported in the literature. Secondly, to use GWPs as they are reported in the literature, gas emissions should be in gas mass units (for example, $\left.\mathrm{kg} \mathrm{CO}_{2}\right)$, not carbon mass $\left(\mathrm{kg} \mathrm{CO}_{2}-\mathrm{C}\right)$ or molar units (mol C). Thirdly-this is one key issue motivating this communication-the GWP is a metric for dealing with the radiative forcing due to a pulse (that is, one-time) emission of a greenhouse gas. Is a metric designed for pulse emissions appropriate for ecosystems where greenhouse gas fluxes are sustained over time? Fourthly-this is another key issue we address-the definition is directed at greenhouse gas emissions. Is the GWP metric appropriate for ecosystems that are greenhouse gas sinks?

Given the frequency with which GWPs are applied to determine whether ecosystems are net sources or sinks of greenhouse gases (that is, have a positive or negative effect on radiative forcing), we feel that it is informative to consider how the use of GWPs affects the conclusions that ecologists draw from greenhouse gas studies. We use a modeling approach to demonstrate that applying a GWP calculated from a single greenhouse gas pulse may provide misleading conclusions about the climatic role of different ecosystems because greenhouse gas fluxes from all natural ecosystems are, in reality, sustained over time. As an alternate metric, we (re)introduce the ecological community to the sustained-flux global warming potential (SGWP), a metric that has also been called the step-change global warming potential (Fuglestvedt and others 1996; Johnson and Derwent 1996; Berntsen and others 2005) and that specifically treats gas emissions as persistent-not one-time-events. Our analyses indicated a large difference in greenhouse gas dynamics depending on whether fluxes are directed into or out of the atmosphere, so we also present a new metric, the sustained-flux global cooling potential (SGCP), for situations where ecosystems remove greenhouse gases from the atmosphere. Both the SGWP and SGCP are similar to the GWP in that they are metrics for comparing the radiative forcing of different greenhouse gases, they apply over a defined time period, and they are mathematically easy to apply. However, we suggest that the SGWP and SGCP are more appropriate than the GWP when greenhouse gas fluxes are persistent and not one-time events, and that using GWPs can yield quantitatively (and sometimes qualitatively) different conclusions about the effects of an ecosystem on global radiative forcing over defined time periods. We hope that this article will stimulate discussion within the ecological community about the wide variety of greenhouse gas metrics, and lead to more appropriate ways of assessing the role of ecosystems as sources/sinks of greenhouse gases and regulators of global climate.

\section{MethodS}

The atmospheric perturbation model described below follows the fate of atmospheric $\mathrm{CO}_{2}, \mathrm{CH}_{4}$, and $\mathrm{N}_{2} \mathrm{O}$ as these greenhouse gases are emitted from, or sequestered by, ecosystems (Figure 1). The model considers how an ecosystem changes (either by 


\section{atmosphere}

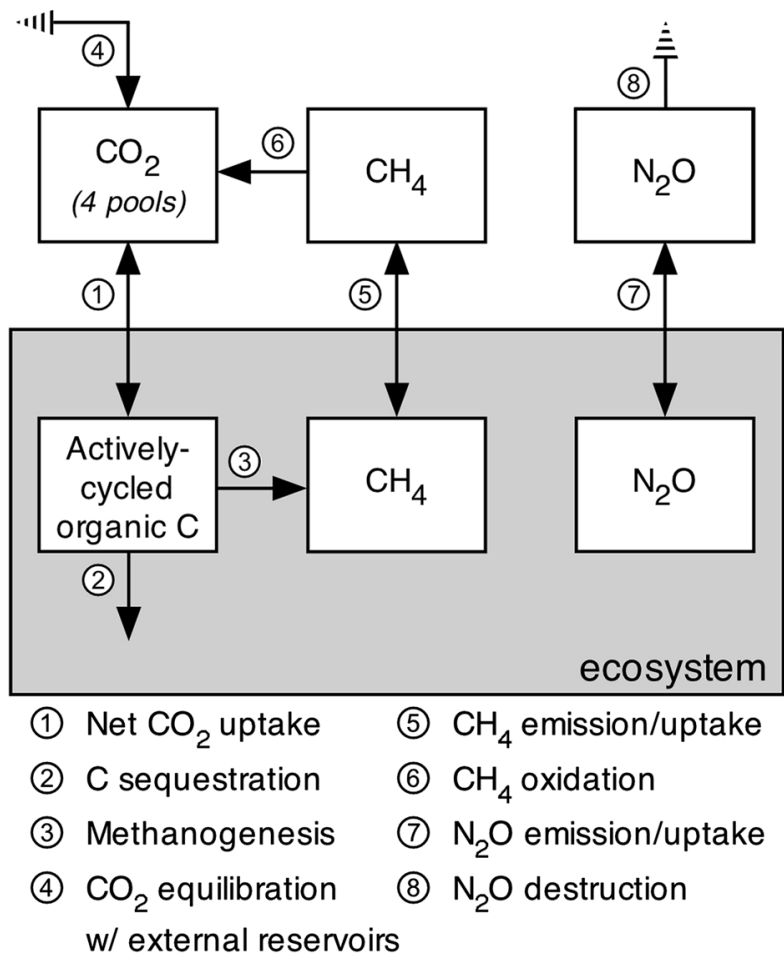

Figure 1. Conceptual structure of the atmospheric perturbation model used for calculating the radiative forcing due to ecosystem $\mathrm{C}$ sequestration, and exchanges of $\mathrm{CH}_{4}$ and $\mathrm{N}_{2} \mathrm{O}$ between an ecosystem and the atmosphere. The atmospheric inventories of $\mathrm{CO}_{2}, \mathrm{CH}_{4}$, and $\mathrm{N}_{2} \mathrm{O}$ were calculated using equations (1)-(3). The soil inventories of actively cycled organic $\mathrm{C}$ (that is, that which is not sequestered), dissolved $\mathrm{CO}_{2}$ (not shown), dissolved $\mathrm{CH}_{4}$, and dissolved $\mathrm{N}_{2} \mathrm{O}$ were assumed to be at steady state (inputs = outputs). When $\mathrm{CH}_{4}$ or $\mathrm{N}_{2} \mathrm{O}$ fluxes are directed into the ecosystem, there is no $\mathrm{CH}_{4}$ oxidation (flux (6) or $\mathrm{N}_{2} \mathrm{O}$ destruction (flux (8)), respectively.

adding or removing) atmospheric greenhouse gases, but does not consider background levels of atmospheric $\mathrm{CO}_{2}, \mathrm{CH}_{4}$, and $\mathrm{N}_{2} \mathrm{O}$. Further, the model assumes equal inputs and outputs to the actively cycling pools of soil organic $\mathrm{C}$ and $\mathrm{CO}_{2} / \mathrm{CH}_{4} / \mathrm{N}_{2} \mathrm{O}$ in soil pores (that is, these pools are in steady state). The model is based on one that was originally presented in Frolking and others (2006), as modified by Neubauer (2014) and described below. After Neubauer (2014) went to press, the Intergovernmental Panel on Climate Change (IPCC) released a new synthesis report. Consequently, we have updated the model with revised radiative efficiencies, atmospheric lifetime numbers, and indirect radiative forcing effects (Myhre and others 2013a). Additionally, we updated the $\mathrm{CO}_{2}$ portion of the model to use the impulse response pa- rameters from Joos and others (2013) instead of an earlier parameterization.

The inventories of ecosystem-derived atmospheric $\mathrm{CH}_{4}$ and $\mathrm{N}_{2} \mathrm{O} \quad\left(M_{\mathrm{CH}_{4}-\mathrm{C}}, \mathrm{g} \mathrm{C} \mathrm{m}^{-2}\right.$; and $M_{\mathrm{N}_{2} \mathrm{O}-\mathrm{N}}, \mathrm{g} \mathrm{N} \mathrm{m}^{-2}$ ) are calculated similarly, where the atmospheric inventory at time $t$ is a function of the emission (or uptake) of $\mathrm{CH}_{4}$ or $\mathrm{N}_{2} \mathrm{O}\left(\mathrm{F}_{\mathrm{CH}_{4}-\mathrm{C}}\right.$, g C m${ }^{-2} \mathrm{y}^{-1}$; and $F_{\mathrm{N}_{2} \mathrm{O}-\mathrm{N}}, \mathrm{g} \mathrm{N} \mathrm{m}^{-2} \mathrm{y}^{-1}$ ), the existing inventories of ecosystem-derived $\mathrm{CH}_{4}$ and $\mathrm{N}_{2} \mathrm{O} \quad\left(M_{\mathrm{CH}_{4}-\mathrm{C},(t-1)}, \quad \mathrm{g} \mathrm{C} \mathrm{m}^{-2}\right.$; and $M_{\mathrm{N}_{2} \mathrm{O}-\mathrm{N},(t-1)}$, $\mathrm{g} \mathrm{N} \mathrm{m}^{-2}$ ), and the first-order removal of these gases from the atmosphere through processes such as $\mathrm{CH}_{4}$ oxidation and the photolysis of $\mathrm{N}_{2} \mathrm{O}$ with ultraviolet light:

$$
M_{\mathrm{CH}_{4}-\mathrm{C},(t)}=F_{\mathrm{CH}_{4}-\mathrm{C}} d t+\left[M_{\mathrm{CH}_{4}-\mathrm{C},(t-1)} \times e^{\left(-d t / \tau_{\mathrm{CH}_{4}}\right)}\right]
$$

$M_{\mathrm{N}_{2} \mathrm{O}-\mathrm{N},(t)}=F_{\mathrm{N}_{2} \mathrm{O}-\mathrm{N}} d t+\left[M_{\mathrm{N}_{2} \mathrm{O}-\mathrm{N},(t-1)} \times e^{\left(-d t / \tau_{\mathrm{N}_{2} \mathrm{O}}\right)}\right]$,

where $\tau_{\mathrm{CH}_{4}}$ and $\tau_{\mathrm{N}_{2} \mathrm{O}}$ are the atmospheric perturbation lifetimes for $\mathrm{CH}_{4}$ and $\mathrm{N}_{2} \mathrm{O}$ (12.4 and 121 years, respectively; Myhre and others 2013a), and $d t$ is the time step of the model ( 0.2 years). When the $M_{\mathrm{CH}_{4}-\mathrm{C}}$ and/or $M_{\mathrm{N}_{2} \mathrm{O}-\mathrm{N}}$ terms are negative (that is, there has been net removal of $\mathrm{CH}_{4}$ and/or $\mathrm{N}_{2} \mathrm{O}$ from the atmosphere), the $e^{(-d t / \tau)}$ terms in equations (1) or (2) are removed to reflect the fact that the atmospheric processes of $\mathrm{CH}_{4}$ oxidation and $\mathrm{N}_{2} \mathrm{O}$ destruction cannot affect gases that are no longer in the atmosphere. Dropping this term results in model formulations that differ for emissions and uptake.

Similar to the calculation of atmospheric inventories of ecosystem-derived $\mathrm{CH}_{4}$ and $\mathrm{N}_{2} \mathrm{O}$, the inventory of atmospheric $\mathrm{CO}_{2}\left(M_{\mathrm{CO}_{2}-\mathrm{C}}, \mathrm{g} \mathrm{C} \mathrm{m}^{-2}\right)$ depends on the rate of ecosystem $\mathrm{CO}_{2}$ flux $\left(\mathrm{F}_{\mathrm{CO}_{2}-\mathrm{C}}\right.$, $\mathrm{g} \mathrm{C} \mathrm{m}^{-2} \mathrm{y}^{-1}$ ); this flux will have a negative sign when the ecosystem is a net sink for atmospheric $\mathrm{CO}_{2}$. The net flux of $\mathrm{CO}_{2}$ between atmosphere and ecosystem will depend on the gross rate of $\mathrm{CO}_{2}$ fixation (gross primary production), the rate of autotrophic and heterotrophic $\mathrm{CO}_{2}$ emissions (ecosystem respiration), and the rate of $\mathrm{CH}_{4}$ emissions $\left(F_{\mathrm{CH}_{4}-\mathrm{C}}\right)$. If we make the simplifying assumption that non-atmospheric sources and sinks of ecosystem C (for example, dissolved organic and inorganic $\mathrm{C}$, allochthonous carbon) are unimportant, then $F_{\mathrm{CO}_{2}-\mathrm{C}}$ can be approximated as $\mathrm{F}_{\mathrm{CO}_{2}-\mathrm{C}}=$ $F_{\text {seq-C }}-F_{\mathrm{CH}_{4}-\mathrm{C}}\left(\mathrm{g} \mathrm{C} \mathrm{m}^{-2} \mathrm{y}^{-1}\right)$, or the balance between rates of ecosystem $\mathrm{C}$ sequestration $\left(F_{\text {seq-C }}\right.$; typically a negative number, representing $\mathrm{CO}_{2}$ removal from the atmosphere) and the $\mathrm{C}$ required to 
support $\mathrm{CH}_{4}$ fluxes $\left(\mathrm{F}_{\mathrm{CH}_{4}-\mathrm{C}}\right.$; a positive number for $\mathrm{CH}_{4}$ emissions, negative for $\mathrm{CH}_{4}$ uptake). Atmospheric $\mathrm{CO}_{2}$ equilibrates with various non-atmospheric reservoirs over a variety of time scales (for example, short-term exchange with the surface ocean, weathering of continental rocks over geological scales; Walker 1991; Siegenthaler and Sarmiento 1993). These feedback processes result in an exchange of $\mathrm{CO}_{2}$ between external biological, hydrological, and geological reservoirs and the atmosphere whenever $\mathrm{CO}_{2}$ is added (or removed) from the atmosphere, and thus buffer perturbations in atmospheric $\mathrm{CO}_{2}$ inventories. Mathematically, this can be modeled as though the atmosphere consists of four non-interacting reservoirs of $\mathrm{CO}_{2}$ (Joos and others 2013). Carbon dioxide can also be added to the atmosphere due to the oxidation of atmospheric $\mathrm{CH}_{4}$ emitted from the ecosystem $\left(M_{\mathrm{CH}_{4}-\mathrm{ox}} ; \mathrm{g} \mathrm{C} \mathrm{m}^{-2}\right)$. Thus, the inventory of ecosystem-derived atmospheric $\mathrm{CO}_{2}$ at any point $t$ can be calculated as follows:

$$
\begin{gathered}
M_{\mathrm{CO}_{2}-\mathrm{C},(t)}=\sum_{i=1}^{4} f_{i}\left(F_{\mathrm{CO}_{2}-\mathrm{C}} d t+M_{\mathrm{CH}_{4}-\mathrm{ox}}\right) \\
+\left[M_{\mathrm{CO}_{2}-\mathrm{C}_{-} i,(t-1)} \times e^{\left(-d t / \tau_{\mathrm{CO}_{2}-i}\right)}\right]
\end{gathered}
$$

where $\tau_{\mathrm{CO}_{2}}$ is the atmospheric perturbation lifetime for each of the four $\mathrm{CO}_{2}$ pools (4.3-394 years, with one pool that stays permanently in the atmosphere) and $f_{i}$ is the relative fractional size of pool $i$ (0.217-0.282; see Joos and others 2013). $M_{\mathrm{CH}_{4}-\mathrm{ox}}$ is the $\left[M_{\mathrm{CH}_{4}-\mathrm{C},(t-1)} \times e^{\left(-d t / \tau_{\mathrm{CH}_{4}}\right)}\right]$ term from equation (1); this entire term is removed when there has been a net removal of $\mathrm{CH}_{4}$ from the atmosphere (that is, $M_{\mathrm{CH}_{4}-\mathrm{C}}<0$ ).

The model was run for periods of 500 years. At each time step, the instantaneous radiative forcing due to each gas $n$ was calculated by multiplying atmospheric inventories converted to $\mathrm{kg} \mathrm{CO}_{2}$, $\mathrm{CH}_{4}$, or $\mathrm{N}_{2} \mathrm{O}\left(M_{n,(t)}\right)$ by the appropriate radiative

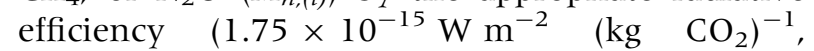
$1.28 \times 10^{-13} \mathrm{~W} \mathrm{~m}^{-2}\left(\mathrm{~kg} \mathrm{CH}_{4}\right)^{-1}$, or $3.83 \times$ $10^{-13} \mathrm{~W} \mathrm{~m}^{-2}\left(\mathrm{~kg} \mathrm{~N}_{2} \mathrm{O}\right)^{-1}$ ) (Myhre and others 2013a). Following accepted practices, the radiative efficiencies for $\mathrm{CH}_{4}$ and $\mathrm{N}_{2} \mathrm{O}$ were multiplied by factors of 1.65 and 0.93 , respectively, to account for the indirect effects of these gases on the global radiation balance (Myhre and others 2013b). For each gas, the time-integrated (that is, cumulative) radiative forcing over the model period was calculated as the sum of the instantaneous radiative forcing values.

The model was run as follows to track the fate of ecosystem-derived greenhouse gases under scenarios of (1) a one-time pulse emission of each gas, and (2) continuous fluxes between ecosystem and atmosphere, modeled as repeated pulses at 0.2-year intervals. Scenario 1: In separate model runs, the initial (time 0) atmospheric inventory of each greenhouse gas was set at $1 \mathrm{~kg} \mathrm{~m}^{-2}$ (representing a one-time pulse), with inventories of the other gases set at $0 \mathrm{~kg} \mathrm{~m}^{-2}$. There were no new inputs or removal by the ecosystem (that is, $F_{n}=0 \mathrm{~g} \mathrm{C}$ or $\left.\mathrm{N} \mathrm{m}^{-2} \mathrm{y}^{-1}\right)$. Scenario 2: The initial atmospheric inventory of each gas was set at $0 \mathrm{~kg} \mathrm{~m}^{-2}$. Individually for each gas, emission or uptake rates of $\mathrm{CO}_{2}, \mathrm{CH}_{4}$, or $\mathrm{N}_{2} \mathrm{O}$ were set at $1 \mathrm{~kg} \mathrm{CO}_{2}, \mathrm{CH}_{4}$, or $\mathrm{N}_{2} \mathrm{O} \mathrm{m}^{-2} \mathrm{y}^{-1}$; the flux of one gas was sustained over the entirety of each 500-year model run and all other fluxes were set at zero. When running the model, each annual emission rate was divided into five equal increments (corresponding to the 0.2 year time step of the model). We also ran a series of model runs where $80-100 \%$ of the fluxes were concentrated during the middle three time points of each year in order to approximate higher biological activity during the growing season. The cumulative radiative forcing over a range of time frames, from 20 to 500 years, differed by trivial amounts $(<0.03 \%)$ relative to the baseline runs where fluxes were constant throughout the entire year.

In each scenario, the cumulative radiative forcing of gas $n$ was calculated over periods of 20, 100, and 500 years. For $\mathrm{CH}_{4}$, the total radiative forcing reflects contributions from ecosystem-derived atmospheric $\mathrm{CH}_{4}, \mathrm{CO}_{2}$ that was produced from $\mathrm{CH}_{4}$ oxidation in the atmosphere, and fluxes of $\mathrm{CO}_{2}$ between the ecosystem and atmosphere that either support $\mathrm{CH}_{4}$ emissions or result from soil $\mathrm{CH}_{4}$ oxidation (Figure 1). The cumulative radiative forcing of each gas over the time period of interest was divided by the cumulative radiative forcing of $\mathrm{CO}_{2}$ over the same period to yield GWP (Scenario 1), SGWP (Scenario 2-emission), or SGCP (Scenario 2-uptake) values. By definition, the GWP, SGWP, and SGCP for $\mathrm{CO}_{2}$ are 1 .

\section{Results AND Discussion}

The global warming potential (GWP) has become a profoundly important tool for quantifying the role of ecosystems in regulating climate and for informing land use policies that mitigate climate change. GWPs have motivated a great deal of contemporary research on ecosystem sources and sinks of greenhouse gases, including the plant and microbial processes that regulate emissions of $\mathrm{CH}_{4}$ and $\mathrm{N}_{2} \mathrm{O}$, gases that are otherwise a trivial component of their respective elemental cycles (Ciais 
and others 2013). Adoption by the Kyoto Protocol in 1997 elevated GWPs from a useful research tool to a legal instrument, a trend that has continued through subsequent adoption by voluntary carbon markets such as the Verified Carbon Standard (Couwenberg and others 2011; VCS 2013), regulatory markets such as California's cap and trade program (Deshpande and others 2014), and offset programs such as Reducing Emissions from Deforestation and forest Degradation (REDD; Canadell and Schulze 2014; UNFCCC 2014). This paper is motivated by the fact that GWPs are being used to translate science into economic and regulatory policy, and by our perception that GWPs may not be the best way for ecologists to communicate research findings related to greenhouse gas fluxes.

\section{Pulse Greenhouse Gas Emissions}

The Scenario 1 calculations followed the fates of individual $1 \mathrm{~kg}$ pulses of $\mathrm{CO}_{2}, \mathrm{CH}_{4}$, and $\mathrm{N}_{2} \mathrm{O}$ that were emitted into the atmosphere at the beginning of separate 500-year model runs. Because of the different radiative efficiencies of each greenhouse gases, the radiative forcing at the beginning of the simulation ranged from $1.8 \mathrm{fW} \mathrm{m}^{-2}$ for $\mathrm{CO}_{2}$ to $355.8 \mathrm{fW} \mathrm{m}^{-2}$ for $\mathrm{N}_{2} \mathrm{O}$ (Figure 2A). The equilibration of atmospheric $\mathrm{CO}_{2}$ with non-atmospheric reservoirs happens over a variety of time scales so the decay dynamics of a $\mathrm{CO}_{2}$ pulse are complex. As modeled, over $50 \%$ of the added $\mathrm{CO}_{2}$ has an effective perturbation lifetime of no more than 37 years, whereas $22 \%$ will effectively remain in the atmosphere forever. Over the course of the 500-year model simulation, the concentration and radiative forcing of $\mathrm{CO}_{2}$ decrease to $28 \%$ of their initial values. In contrast, the atmospheric removal of $\mathrm{N}_{2} \mathrm{O}$ is modeled as a first-order decay process (lifetime $=121$ years), with concentrations and radiative forcing decreasing exponentially; the instantaneous radiative forcing of $5.7 \mathrm{fW} \mathrm{m}^{-2}$ after 500 years represents approximately $1.6 \%$ of the initial forcing from this gas. With its short atmospheric perturbation lifetime (12.4 years), the pulse of $\mathrm{CH}_{4}$ decayed rapidly such that $90 \%$ of the $\mathrm{CH}_{4}$ was removed within the first 30 years of the simulation and only $1 \%$ of the $\mathrm{CH}_{4}$ remained after 100 years. Despite the rapid atmospheric disappearance of the $\mathrm{CH}_{4}$, the radiative forcing due to the initial $\mathrm{CH}_{4}$ pulse never reached zero because the oxidation of atmospheric $\mathrm{CH}_{4}$ produces $\mathrm{CO}_{2}$ that contributes radiative forcing and is governed by the complex (and slower) $\mathrm{CO}_{2}$ equilibrium dynamics described above. After 100 years, $97 \%$ of
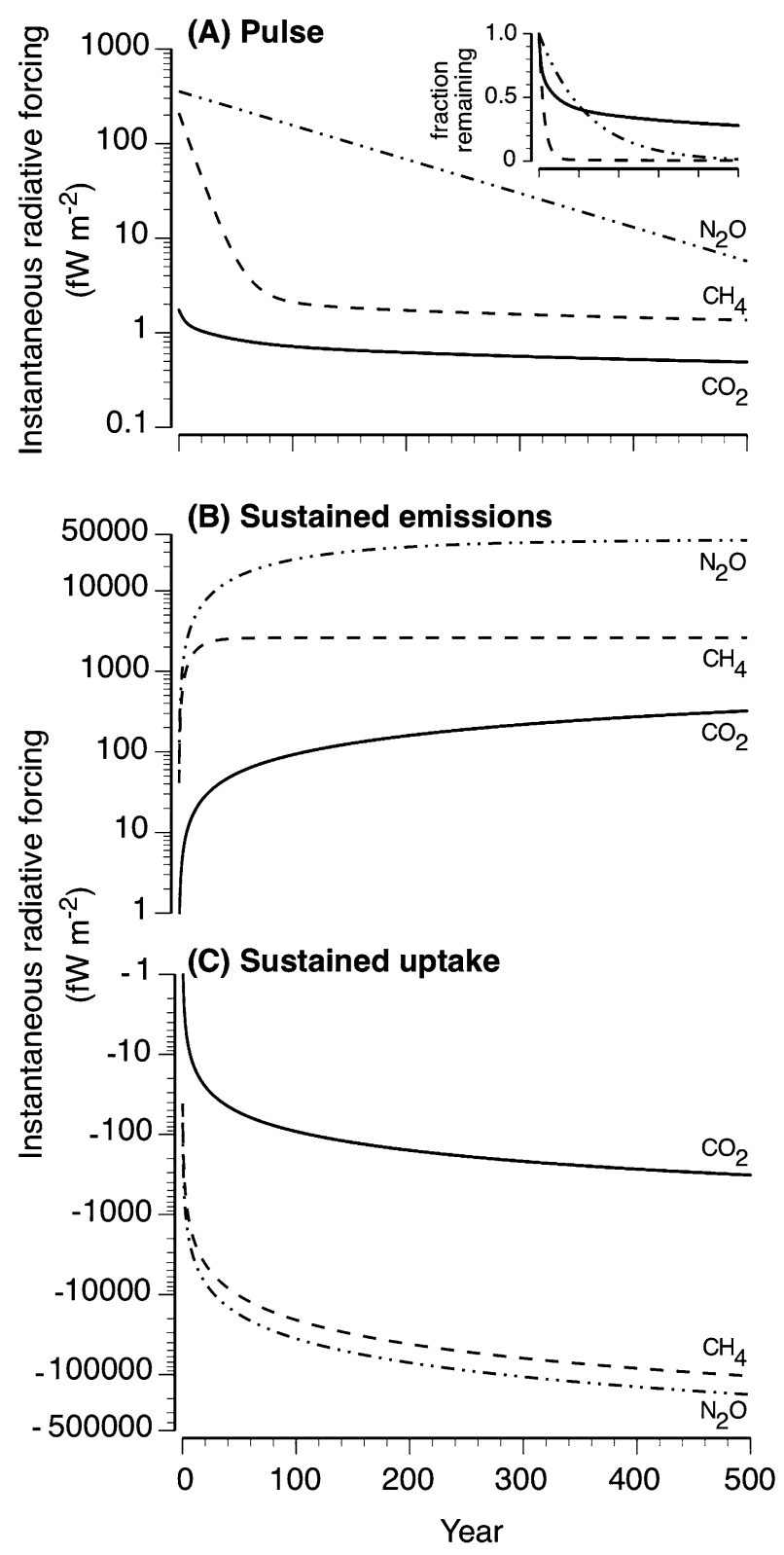

Figure 2. (A) Instantaneous radiative forcing of $\mathrm{CO}_{2}$, $\mathrm{CH}_{4}$, and $\mathrm{N}_{2} \mathrm{O}$ following a $1 \mathrm{~kg}$ pulse addition of each gas at time 0 and the decay of each gas over a 500-year period. Inset shows the fraction of each gas remaining over time. The remainder of the figure shows radiative forcing due to sustained emissions $(\mathbf{B})$ or sustained uptake $(\mathbf{C})$ of $\mathrm{CO}_{2}, \mathrm{CH}_{4}$, and $\mathrm{N}_{2} \mathrm{O}$ throughout the model period. All fluxes were $1 \mathrm{~kg} \mathrm{~m}^{-2} \mathrm{y}^{-1}$. In all panels, the " $\mathrm{CH}_{4}$ " curves include any radiative forcing by $\mathrm{CO}_{2}$ that was produced from the oxidation of atmospheric $\mathrm{CH}_{4}$. Note the logarithmic scale on the $y$ axes. $\mathrm{fW}=10^{-15} \mathrm{~W}$.

the instantaneous radiative forcing attributable to the initial $\mathrm{CH}_{4}$ pulse was due to this $\mathrm{CO}_{2}$. Remembering that GWP is a cumulative value, nearly $8 \%$ of methane's cumulative radiative forcing at 
the 100-year point (and 24\% after 500 years) was attributable to $\mathrm{CO}_{2}$ that was produced by atmospheric $\mathrm{CH}_{4}$ oxidation.

The GWP values calculated from the Scenario 1 model simulations show that GWP varies as a nonlinear function of time (Figure 3), with these temporal patterns due to the differing atmospheric dynamics of each gas. Notwithstanding the complexities associated with atmospheric $\mathrm{CH}_{4}$ oxidation, $\mathrm{CH}_{4}$ decays faster than $\mathrm{CO}_{2}$ equilibrates with external reservoirs so the GWP of $\mathrm{CH}_{4}$ steadily decreases from 120 at time 0 to 87 at 20 years, 32 at 100 years, and 11 at 500 years (Table 1). Recall that the value of 120 at time 0 is the ratio of the radiative efficiencies of $\mathrm{CH}_{4}$ and $\mathrm{CO}_{2}$ after accounting for the indirect forcings associated with $\mathrm{CH}_{4}$. In contrast, the GWP for $\mathrm{N}_{2} \mathrm{O}$ increases from 203 at time 0 (the ratio of the radiative efficiencies of $\mathrm{N}_{2} \mathrm{O}$ and $\mathrm{CO}_{2}$, after indirect effects) to 260 at 20 years and a maximum of 273 at roughly 50 years before decreasing to 263 at 100 years, and 132 at 500 years (Figure 3; Table 1). These temporal dynamics reflect the rapid initial disappear-

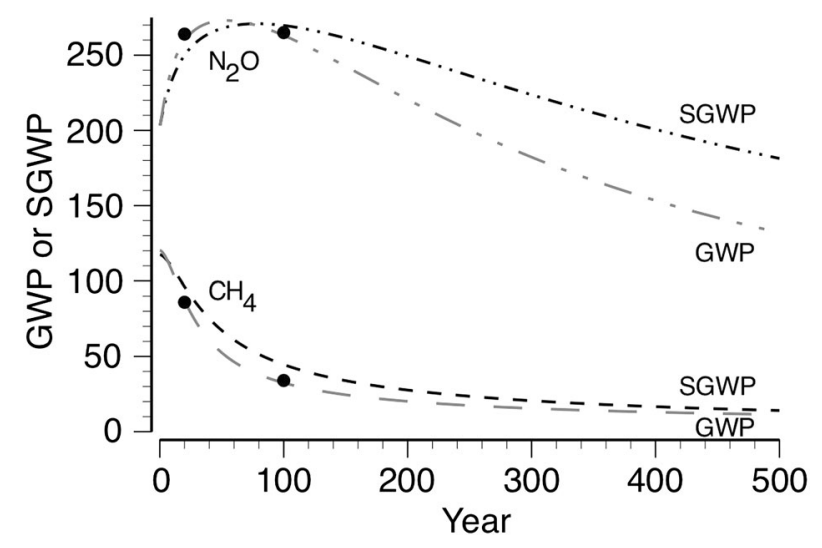

Figure 3. Temporal variations in the global warming potential (GWP) and sustained-flux global warming potential (SGWP) of $\mathrm{CH}_{4}$ and $\mathrm{N}_{2} \mathrm{O}$, calculated as the $\mathrm{cu}$ mulative (time-integrated) radiative forcing of each gas (that is, the area under each curve in Figure 2) relative to the cumulative radiative forcing of $\mathrm{CO}_{2}$ over the same time period. The GWP values were calculated following the emission of a $1 \mathrm{~kg}$ pulse of each gas at the start of a model run. The SGWP values assumed continuous emissions of $\mathrm{CH}_{4}$ and $\mathrm{N}_{2} \mathrm{O}$, thus representing the amount of $\mathrm{CO}_{2}$ (in $\mathrm{kg} \mathrm{CO}_{2} \mathrm{~m}^{-2} \mathrm{y}^{-1}$ ) that must be sequestered to offset the emissions of $1 \mathrm{~kg} \mathrm{~m}^{-2} \mathrm{y}^{-1}$ of $\mathrm{CH}_{4}$ or $\mathrm{N}_{2} \mathrm{O}$. The GWPs and SGWPs for the commonly reported 20-, 100-, and 500-year periods are summarized in Table 1. Black symbols indicate the GWP values as reported in Myhre and others (2013a), that latest IPCC report does not include 500-year GWPs. ance of atmospheric $\mathrm{CO}_{2}$ (relative to $\mathrm{N}_{2} \mathrm{O}$; Figure $2 \mathrm{~A}$ inset) followed by more rapid $\mathrm{N}_{2} \mathrm{O}$ decay (relative to $\mathrm{CO}_{2}$ ) during later stages.

For $\mathrm{CH}_{4}$, the modeled 20-year GWP of 87 is similar to the value of 85 reported in the 2013 IPCC report (value for "fossil $\mathrm{CH}_{4}$," which includes $\mathrm{CO}_{2}$ from $\mathrm{CH}_{4}$ oxidation; Myhre and others 2013a). Similarly, the GWP at 100 years is also somewhat larger than that from the latest IPCC report (32 vs. 30). For $\mathrm{N}_{2} \mathrm{O}$, there is even better agreement (within 2\%) between our GWPs and those of the IPCC. Given that GWPs summarized in the IPCC reports are calculated with more advanced models than used here and have an estimated uncertainty of $\pm 30-40 \%$ (Myhre and others 2013b), we consider that our simple atmospheric perturbation model is sufficiently describing the atmospheric dynamics of single pulses of $\mathrm{CO}_{2}, \mathrm{CH}_{4}$, and $\mathrm{N}_{2} \mathrm{O}$ and thus turn our attention to the behavior of the system when fluxes are sustained over time.

\section{Sustained Ecosystem Greenhouse Gas Fluxes}

The second set of scenarios involved situations where greenhouse gas fluxes (either uptake or emission to the atmosphere) were sustained over time; these scenarios produced very different time series of radiative forcing than those following a single pulse emission. When emissions are continuous from year-to-year, the atmospheric concentration and instantaneous radiative forcing of ecosystem-derived $\mathrm{CH}_{4}$ or $\mathrm{N}_{2} \mathrm{O}$ will reach steady state when the rates of atmospheric $\mathrm{CH}_{4}$ oxidation or $\mathrm{N}_{2} \mathrm{O}$ destruction are balanced by new inputs from the ecosystem. This steady state is reached after roughly four atmospheric lifetimes ( $\sim 50$ years for $\mathrm{CH}_{4}$ and $\sim 480$ years for $\mathrm{N}_{2} \mathrm{O}$; Figure 2B). In contrast, the atmospheric reservoir of $\mathrm{CO}_{2}$ never reaches steady state because one of the modeled $\mathrm{CO}_{2}$ pools remains in the atmosphere over the time scales of the simulation; this is associated with the geological scale weathering of continental rocks. Thus, sustained ecosystem $\mathrm{CO}_{2}$ emissions will cause radiative forcing to steadily increase over time, with climatic effects continuing long after the impacts of $\mathrm{CH}_{4}$ or $\mathrm{N}_{2} \mathrm{O}$ emissions have reached steady state.

Many studies addressing the question of whether an ecosystem is a net source or sink of greenhouse gases have examined the balance between ecosystem $\mathrm{CO}_{2}$ sequestration (which contributes negative radiative forcing) and emissions of $\mathrm{CH}_{4}$ and/or $\mathrm{N}_{2} \mathrm{O}$ to the atmosphere (positive radiative forcing). Under these conditions, the GWPs and SGWPs for $\mathrm{CH}_{4}$ 
Table 1. Global Warming Potentials (GWPs), Sustained-Flux Global Warming Potentials (SGWPs), and Sustained-flux Global Cooling Potentials (SGCPs)

\begin{tabular}{llccc}
\hline Gas & (Years) & GWP & (Emissions) & (Uptake) \\
& Time frame & SGWP & 1 \\
\hline $\mathrm{CO}_{2}$ & any & 1 & 1 & 153 \\
$\mathrm{CH}_{4}$ & 20 & 87 & 96 & 203 \\
& 100 & 32 & 45 & 288 \\
& 500 & 11 & 14 & 264 \\
$\mathrm{~N}_{2} \mathrm{O}$ & 260 & 250 & 349 \\
& 100 & 263 & 270 & 491
\end{tabular}

The GWP values were calculated from a single gas pulse that was allowed to decay for 20, 100, or 500 years (Figure 2A). The SGWP and SGCP values were calculated assuming a sustained gas flux rate (emission or uptake, respectively) of $1 \mathrm{~kg} \mathrm{~m}^{-2} y^{-1}$ over the relevant time period (Figure $2 B$ and C). The SGWP indicates how many kilograms of $\mathrm{CO}_{2}$ must be sequestered to offset the emission of $1 \mathrm{~kg}$ of $\mathrm{CH}_{4}$ or $\mathrm{N}_{2} \mathrm{O}$; also see Figure 3. The SGCP indicates how many kilograms of CO must be sequestered to have the same cooling effect as the uptake of $1 \mathrm{~kg}$ of $\mathrm{CH}_{4}$ or $\mathrm{N}_{2} \mathrm{O}$.

and $\mathrm{N}_{2} \mathrm{O}$ follow similar temporal trajectories but the SGWP is generally larger than the GWP; the major exception to this pattern is for $\mathrm{N}_{2} \mathrm{O}$ at time scales $<70$ years (Table 1; Figure 3 ). At the commonly used 100-year time horizon, the SGWP for $\mathrm{CH}_{4}$ is approximately $40 \%$ higher than the corresponding GWP. Thus, when fluxes are sustained over time, the emission of $1 \mathrm{~kg} \mathrm{CH}_{4} \mathrm{~m}^{-2} \mathrm{y}^{-1}$ would be offset by the persistent sequestration of $45 \mathrm{~kg}$ $\mathrm{CO}_{2} \mathrm{~m}^{-2} \mathrm{y}^{-1}$ (Table 1). An ecosystem with fluxes in the ratio of $32 \mathrm{~kg} \mathrm{CO}_{2}$ sequestered per $1 \mathrm{~kg} \mathrm{CH}_{4}$ emitted would not be greenhouse gas neutral, as would be inferred if one used the 100-year GWP value calculated herein, but would actually contribute positive radiative forcing (that is, would have a net warming effect). The situation is similar for $\mathrm{N}_{2} \mathrm{O}$, except that the 100-year SGWP for $\mathrm{N}_{2} \mathrm{O}$ emissions is only a few percent greater than the 100-year GWP (Table 1).

It should be reiterated that the SGWP derived from these sustained flux scenarios is conceptually similar to the step-change global warming potential that has been calculated for a variety of gases, including $\mathrm{CH}_{4}$, although we have not yet found a previously calculated step-change GWP for $\mathrm{N}_{2} \mathrm{O}$ (Harvey 1993; Fuglestvedt and others 1996; Johnson and Derwent 1996; Berntsen and others 2005). The SGWP values that we report (Table 1) were calculated using the latest estimates of atmospheric lifetimes, radiative efficiencies, and indirect effects of greenhouse gases on radiative forcing, so our SGWP numbers are not directly comparable to those from previous studies. Even so, our calculated GWP:SGWP ratios for emissions of $\mathrm{CH}_{4}$ (lifetime 12.4 years) and $\mathrm{N}_{2} \mathrm{O}$ (121 years) were similar to those for hypothetical gases with lifetimes of 10 and 100 years, respectively (Berntsen and others 2005). One important difference with previous work is that our calculations explicitly consider the uptake of greenhouse gases, and not emissions only. This seemingly trivial difference has important consequences for the application of greenhouse gas metrics to ecosystems.

Greenhouse gas metrics like GWP typically deal with emissions of gases to the atmosphere because these metrics were developed in the context of understanding, managing, and limiting the climatic effects of anthropogenic greenhouse gas production (Fuglestvedt and others 2003). However, ecosystems can either emit greenhouse gases or remove them from the atmosphere. Because the atmospheric dynamics of $\mathrm{CO}_{2}$ are controlled by firstorder equilibration with non-atmospheric reservoirs and not by the chemical destruction of $\mathrm{CO}_{2}$ (compare with chemical loss mechanisms for $\mathrm{CH}_{4}$ and $\mathrm{N}_{2} \mathrm{O}$ ), the sustained removal (sequestration) of atmospheric $\mathrm{CO}_{2}$ produces a time course of radiative forcing that is equal in magnitude, but opposite in sign, to that produced by ecosystem $\mathrm{CO}_{2}$ emissions (compare Figure 2B and $\mathrm{C}$ ). As noted above, scenarios with $\mathrm{CH}_{4}$ or $\mathrm{N}_{2} \mathrm{O}$ emissions to the atmosphere will approach steady state (Figure 2B) as emissions of these gases are counterbalanced by chemical destruction in the atmosphere. In contrast to the atmosphere where concentrations are the balance of two competing processes, the ecosystem uptake of atmospheric $\mathrm{CH}_{4}$ and $\mathrm{N}_{2} \mathrm{O}$ produces a linear decrease in radiative forcing from these gases (Figure 2C). Applying an emissions model to uptake fluxes would mathematically imply that removal from the atmosphere would trigger new inputs to the atmosphere, but there are no important processes that add these gases to the atmosphere from other reservoirs once the gases have been taken up by an ecosystem. Thus, atmospheric $\mathrm{CH}_{4}$ and $\mathrm{N}_{2} \mathrm{O}$ exhibit very different trajectories over 
time depending on whether the gas fluxes are directed into or out of the ecosystem. This asymmetrical behavior has implications because it means that greenhouse gas uptake has a larger impact than emissions on net radiative forcing. These profound differences in greenhouse gas behavior as a function of flux direction lead to our suggestion that it would be more appropriate to use different metrics when fluxes are directed into vs. out of ecosystems (the SGCP and SGWP, respectively) than to use a single metric for all fluxes.

The net uptake of $\mathrm{CH}_{4}$ and/or $\mathrm{N}_{2} \mathrm{O}$ is certainly not a universal characteristic of ecosystems, but sites that can remove these gases from the atmosphere would be very effective at reducing radiative forcing. A synthesis of carbon fluxes in North American wetlands reported a net annual $\mathrm{CH}_{4}$ uptake for only 5 of 113 sites (Bridgham and others 2006). In contrast, upland ecosystems including forests, agricultural lands, and grasslands are considered global $\mathrm{CH}_{4}$ sinks (Le Mer and Roger 2001; Dutaur and Verchot 2007). On a global basis, terrestrial and aquatic ecosystems are net sources of $\mathrm{N}_{2} \mathrm{O}$, with higher $\mathrm{N}_{2} \mathrm{O}$ emissions in systems that have higher availability of reactive nitrogen (Ciais and others 2013). However, a number of studies have measured $\mathrm{N}_{2} \mathrm{O}$ uptake in ecosystems ranging from forests to pastures, with $\mathrm{N}_{2} \mathrm{O}$ uptake being most common in soils with a high water content and low inorganic $\mathrm{N}$ availability (Chapuis-Lardy and others 2007). A recent synthesis of wetland $\mathrm{N}_{2} \mathrm{O}$ fluxes supports these findings, showing net $\mathrm{N}_{2} \mathrm{O}$ uptake primarily in low-nutrient freshwater and coastal wetlands, and high emissions in wetlands exposed to high nitrogen loading (Moseman-Valtierra 2012). The removal of $1 \mathrm{~kg}$ $\mathrm{CH}_{4} \mathrm{~m}^{-2} \mathrm{y}^{-1}$ or $1 \mathrm{~kg} \mathrm{~N}_{2} \mathrm{O} \mathrm{m}^{-2} \mathrm{y}^{-1}$, sustained over a 100 -year period, would be equivalent to removing 203 or $349 \mathrm{~kg} \mathrm{CO}_{2} \mathrm{~m}^{-2} \mathrm{y}^{-1}$, respectively (Table 1); these SGCPs are 350 and $30 \%$ greater (for $\mathrm{CH}_{4}$ and $\mathrm{N}_{2} \mathrm{O}$, respectively) than the SGWPs for the same time frame. Because of differences in the trajectories of gases over time between emissions and uptake (Figure 2B vs. C), there is a greater difference between the SGWP and SGCP at longer time frames (Table 1).

The SGWP and SGCP values, like GWPs, are additive when multiple greenhouse gases are considered. For example, over a 100-year time period, the radiative forcing due to the continuous emission of $1 \mathrm{~kg} \mathrm{CH}_{4} \mathrm{~m}^{-2} \mathrm{y}^{-1}$ and $1 \mathrm{~kg} \mathrm{~N}_{2} \mathrm{O} \mathrm{m}^{-2} \mathrm{y}^{-1}$ would be offset if $\mathrm{CO}_{2}$ sequestration rates were $315 \mathrm{~kg} \mathrm{CO}_{2} \mathrm{~m}^{-}$ ${ }^{2} \mathrm{y}^{-1} \quad\left(=\mathrm{SGWP}_{\mathrm{CH}_{4}, 100 \mathrm{y}}+\mathrm{SGWP}_{\mathrm{N}_{2} \mathrm{O}, 100 \mathrm{y}} ;\right.$ Table 1$)$. Any reader who wishes to apply these SGWP and SGCP values to determine whether a site is a source or sink of greenhouse gases should be aware that these ratios are based on rates of ecosystem $\mathrm{CO}_{2}$ sequestration, not net rates of $\mathrm{CO}_{2}$ uptake. This decision was based on practicality, as our impression is that more ecosystem scientists measure $C$ sequestration (for example, by quantifying wood accumulation and/or using ${ }^{137} \mathrm{Cs}$ and ${ }^{210} \mathrm{~Pb}$ radiodating techniques in accreting soils) than develop robust annual estimates of net ecosystem $\mathrm{CO}_{2}$ exchange (for example, by using flux chambers or eddy covariance methods).

\section{Implications of Using GWP versus SGWP and SGCP}

The SGWP and SGCP are alternates to the commonly used GWP that can provide a more robust estimate of the greenhouse gas source/sink status of ecosystems over a defined time period (for example, 100 years) because the calculations are based on greenhouse gas fluxes that are sustained over the entire period of interest. In contrast, the use of GWPs requires the implicit assumption that these fluxes occur as a single pulse and are not sustained over time. For ecosystems, this assumption is rarely, if ever, justified. An important question then is as follows: How does the use of GWPs instead of SGWPs or SGCPs affect interpretations of whether an ecosystem is a net source or sink of greenhouse gases (that is, radiative balance), or how a management activity changes the radiative balance of an ecosystem (that is, radiative forcing)? At the commonly used 100-year time horizon, using the GWP instead of the SGWP when considering $\mathrm{CH}_{4}$ and $\mathrm{N}_{2} \mathrm{O}$ emissions would cause one to quantitatively overestimate an ecosystem's role as a greenhouse gas sink or, conversely, underestimate its role as a greenhouse gas source (Figure 3). If the ecosystem ratio of $\mathrm{CO}_{2}$ sequestration to $\mathrm{CH}_{4} / \mathrm{N}_{2} \mathrm{O}$ emission rates was greater than both GWP and SGWP, the qualitative conclusion that a site is a net greenhouse gas sink would not change regardless of whether GWP or SGWP were used (Figure 4). However, the quantitative assessment of the strength of the site's source or sink status would differ as a function of the metric used. Similarly, if the ratio was less than both the GWP and SGWP, the qualitative conclusion that the site is a net greenhouse gas source would not change. A problem exists, however, if the ecosystem sequestration:emission ratio lies between the GWP and SGWP. In this case, one metric would indicate that the site or activity had a net cooling effect on the climate, whereas the other would indicate a net warming effect over the same time period. The potential for conflicting conclusions from the two 

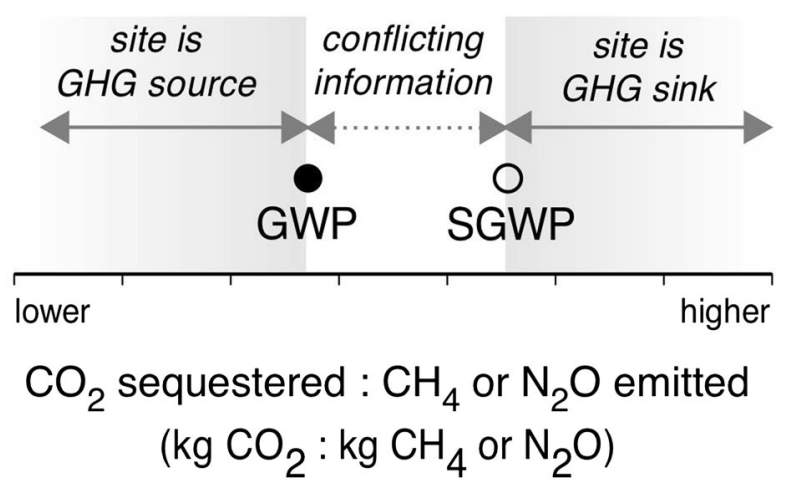

Figure 4. Interpretation of an ecosystem's status as a source or sink of greenhouse gases can depend on whether one uses the GWP or SGWP. When a site's ratio of $\mathrm{CO}_{2}$ sequestration to $\mathrm{CH}_{4}$ or $\mathrm{N}_{2} \mathrm{O}$ emissions lies between the GWP and SGWP, these indices provide conflicting information about the greenhouse gas status of the site. Conversely, when the ratio of sequestration to emissions is either greater than both indices (greenhouse gas sink) or less than both (greenhouse gas source) one would reach the same qualitative determination about the source/sink status of a particular site regardless of which index was used, but the GWP and SGWP would give different quantitative assessments of the site's strength as a source or sink. GHG greenhouse gas.

metrics changes with time horizon; for the three time horizons shown in Table 1, the proportional difference between GWP and SGWP is greatest at 100 years for $\mathrm{CH}_{4}$ and at 500 years for $\mathrm{N}_{2} \mathrm{O}$. The same issue applies to comparisons of GWP with other alternative metrics, illustrating that the choice of a metric has the potential to influence conclusions about how changes in ecosystem processes will affect climate.

Using two separate global data compilations, we illustrate how the choice of a greenhouse gas metric can affect the calculated greenhouse gas source/sink status of an ecosystem, with potential management implications. First, we consider the global exchanges of $\mathrm{CH}_{4}$ and $\mathrm{N}_{2} \mathrm{O}$ between upland and wetland ecosystems and the atmosphere (Table 2; Ciais and others 2013; GCP 2013). Collectively, the fluxes of $\mathrm{CH}_{4}$ and $\mathrm{N}_{2} \mathrm{O}$ from upland and wetland systems contribute 10.2-14.7 $\mathrm{Pg} \mathrm{CO}_{2-}^{-}$ equivalents $\mathrm{y}^{-1}$ to the atmosphere, with the range reflecting use of the GWP, SGWP, and SGCP gas metrics that have been discussed in this article (there is considerable additional variability due to scientific uncertainty in the flux estimates themselves). The effect of the different greenhouse gas metrics is most apparent when examining upland soils, where the uptake of $\mathrm{CH}_{4}$ has the same cooling effect as the sequestration of 0.9-5.7 $\mathrm{Pg} \mathrm{CO}_{2} \mathrm{y}^{-1}$ (calculated using the 100-year GWPs and SGCPs, respectively). This six-fold difference also reflects the asymmetry in greenhouse gas behavior for uptake and emissions (Figure 2B vs. 2C; Table 1), and indicates how the estimate of the net cooling effect of upland systems would be significantly affected by the choice of metric. Note that applying the SGWP values for both emissions and uptake (the 'SGWP' column of Table 2) produces a flux value that is more similar to that calculated using GWPs and consequently underestimates the significant cooling that can result from greenhouse gas uptake by ecosystems. The fact that greenhouse gas metrics are markedly different depending on the direction of gas transport (that is, emissions versus uptake) has not been previously recognized in the calculation or criticism of existing greenhouse gas metrics. For ecosystems that emit $\mathrm{CH}_{4}$ and $\mathrm{N}_{2} \mathrm{O}$ to the atmosphere, the $\mathrm{CO}_{2}$-equivalent fluxes vary by factors of 1.41 for $\mathrm{CH}_{4}$ and 1.03 for $\mathrm{N}_{2} \mathrm{O}$ (Table 2), which are the ratios of the 100-year SGWPs:GWPs for these gases (Table 1). In some cases, the effect of using different greenhouse gas metrics can be greater than the scientific uncertainty in the flux estimates themselves. For example, estimates of $\mathrm{CH}_{4}$ emissions from rice paddies range from 33 to $40 \mathrm{Tg} \mathrm{CH}_{4} \mathrm{Y}^{-1}$ (Table 2; GCP 2013). These emissions are equivalent to $1.5-1.8 \mathrm{Pg}$ $\mathrm{CO}_{2}$-eq $\mathrm{y}^{-1}$ (calculated using 100-year SGWP) or 1.1-1.3 Pg $\mathrm{CO}_{2}$-eq $\mathrm{y}^{-1}$ (using 100-year GWP); note that these ranges do not overlap. When considering total fluxes to/from upland and wetland ecosystems, there is a difference of $4.4 \mathrm{Pg} \mathrm{CO}_{2}$-eq $\mathrm{y}^{-1}$ between the low and high best estimates of the ecosystem $\mathrm{CH}_{4}$ and $\mathrm{N}_{2} \mathrm{O}$ fluxes (Table 2). For context, this is larger than the annual emissions of $\mathrm{CO}_{2}$ due to land use change (4.0 $\mathrm{Pg} \mathrm{CO}_{2} \mathrm{Y}^{-1}$; Ciais and others 2013), further illustrating how the choice of a metric can have significant effects on how one interprets the importance of ecosystems as contributors to global greenhouse gas budgets.

As a second example, we consider tidal marshes where there is a general trend of decreasing $\mathrm{CH}_{4}$ emissions as one moves from freshwater toward saline (oceanic) systems (Bartlett and others 1987; Poffenbarger and others 2011). Using the GWP to compare $\mathrm{CH}_{4}$ emission rates with soil carbon sequestration rates, Poffenbarger and others (2011) estimated that there was at least a $95 \%$ chance that tidal marshes at salinities of at least 18 sequester enough carbon to offset $\mathrm{CH}_{4}$ emissions. More precisely, above a salinity of 18 , the $\mathrm{CO}_{2}$-equivalent $\mathrm{CH}_{4}$ emissions of the $5 \%$ of marshes with the highest $\mathrm{CH}_{4}$ emissions were less than the $\mathrm{CO}_{2}-$ equivalent sequestration in the $5 \%$ of marshes 
Table 2. Global $\mathrm{CH}_{4}$ and $\mathrm{N}_{2} \mathrm{O}$ Fluxes from Upland and Wetland Ecosystems (Ciais and others 2013; GCP 2013)

\begin{tabular}{|c|c|c|c|c|}
\hline & \multirow{2}{*}{$\begin{array}{l}\left(\mathrm{Tg} \mathrm{Y}^{-1}\right) \\
\mathrm{CH}_{4} \text { and } \mathrm{N}_{2} \mathrm{O} \text { flux }\end{array}$} & \multicolumn{3}{|l|}{$\left(\mathrm{Pg} \mathrm{CO}_{2}-\mathrm{eq} \mathrm{Y}^{-1}\right)$} \\
\hline & & SGWP/SGCP & SGWP & GWP \\
\hline \multicolumn{5}{|l|}{$\mathrm{CH}_{4}$} \\
\hline Natural wetlands & 217 (177 to 284$)$ & $9.8(8.0$ to 12.8$)$ & $9.8(8.0$ to 12.8$)$ & $6.9(5.7$ to 9.1$)$ \\
\hline Rice paddies & $36(33$ to 40$)$ & $1.6(1.5$ to 1.8$)$ & $1.6(1.5$ to 1.8$)$ & $1.2(1.1$ to 1.3$)$ \\
\hline Upland soils & $-28(-47$ to -9$)$ & $-5.7(-9.5$ to -1.8$)$ & $-1.3(-2.1$ to -0.4$)$ & $-0.9(-1.5$ to -0.3$)$ \\
\hline \multicolumn{5}{|l|}{$\mathrm{N}_{2} \mathrm{O}$} \\
\hline Upland soils: natural & $10.4(5.2$ to 14.1$)$ & $2.8(1.4$ to 3.8$)$ & $2.8(1.4$ to 3.8$)$ & 2.7 (1.4 to 3.7$)$ \\
\hline Upland soils: agricultural & $6.4(2.7$ to 7.5$)$ & $1.7(0.7$ to 2.0$)$ & $1.7(0.7$ to 2.0$)$ & $1.7(0.7$ to 2.0$)$ \\
\hline \multicolumn{5}{|l|}{ Total } \\
\hline Upland and wetland & - & $10.2(2.0$ to 18.6$)$ & $14.7(9.5$ to 20.0$)$ & $11.6(7.3$ to 15.8$)$ \\
\hline \multicolumn{5}{|c|}{$\begin{array}{l}\text { Negative values indicate uptake by the ecosystem. In the " } \mathrm{CH}_{4} \text { and } \mathrm{N}_{2} \mathrm{O} \text { flux" column, the reported best estimate flux is shown, with minimum and maximum flux estimates in } \\
\text { parentheses. This uncertainty is propagated through the other columns. For the "SGWP/SGCP" column, we used } S G W P \text { or } S G C P \text { values to calculate } C O_{2} \text {-equivalent fluxes, as } \\
\text { appropriate, depending on whether fluxes were directed into vs. out of the ecosystem. For the "SGWP" column, we used } S G W P \text { values, regardless of the actual direction of the } \\
\text { flux. For the "GWP" column, we used } G W P \text { values calculated in this study. All calculations of } C O_{2} \text {-equivalent fluxes use a 100-year time frame and metric values from } \\
\text { Table 1. } \mathrm{CO}_{2}-e q=\mathrm{CO}_{2} \text { equivalents, } \mathrm{Tg}=10^{12} \mathrm{~g}, \mathrm{Pg}=10^{15} \mathrm{~g} \text {. }\end{array}$} \\
\hline
\end{tabular}

with the lowest soil carbon accumulation rates, making 18 a conservative delineation. Using the SGWP to make the same comparison, a marsh would require a higher carbon sequestration rate in order for the system to be conservatively climate neutral over a 100-year period; at a salinity of about 18, the probability that $\mathrm{C}$ sequestration would offset $\mathrm{CH}_{4}$ emissions drops from 95 to $85 \%$. To keep a $95 \%$ level of certainty, the salinity threshold would need to increase by roughly $4-5$ salinity units. Thus, although both the GWP and SGWP indicate that the cooling effect of carbon sequestration in high-salinity tidal salt marshes exceeds the warming effects from $\mathrm{CH}_{4}$ emissions, using GWP instead of SGWP to make this comparison adds a degree of uncertainty to the design and implementation of wetland creation, restoration, and protection activities (for example, "blue carbon" projects) that can affect project viability or the value of carbon credits issued to the project.

\section{Alternative Metrics and Other Approaches}

One of our main goals in this article is to begin a discussion about whether the use of GWPs as practiced by the ecological community is appropriate for determining whether natural or management-driven changes in greenhouse gas sources or sinks have a net warming or cooling effect on climate. Although we suggest that the SGWP and SGCP are more appropriate than the GWP, it is not clear that any single metric is appropriate to apply across the full spectrum of ecological research because different study goals may require different metrics. An advantage of the GWP, SGWP, and SGCP is that they are relatively straightforward to apply; one only needs to know rates of greenhouse gas uptake/emission to assess the relative radiative forcing due to each gas. This simplicity is one reason why the GWP has been widely adopted (Myhre and others 2013a). However, there are fundamental questions and issues associated with the usage and interpretation of GWPs; this topic has been covered extensively in the climate literature (Harvey 1993; O'Neill 2000; Smith and Wigley 2000; Fuglestvedt and others 2003; Shine 2009; Pierrehumbert 2014). At the risk of being redundant, we briefly highlight some of the issues and note that these concerns are generally applicable to the SGWP and SGCP metrics as well. Although ecosystem scientists and policy makers generally apply GWPs over a 100-year time frame, it is not clear what the correct time frame should be, or even that there is a "correct" time frame (Rodhe 1990; Shine and others 1990). Implicitly, neither the GWP nor SGWP considers any gas that remains in the atmosphere after the time period of interest (O'Neill 2000), which can result in policies that favor abatement of short-lived gases while delaying mitigation of longer-lived gases whose climatic effects persist beyond the time frame of the greenhouse gas metric (Pierrehumbert 2014). Because these metrics were calculated over a defined time period, they cannot deal with temporally variable fluxes (Frolking and others 2006). Finally, these metrics have "warming" in their name (or "cooling" in the case of the SGCP) but deal only with cumulative radiative forcing and not with temperature change (Fuglestvedt and others 2003). 
Despite the many shortcomings, the GWP has been widely adopted as a policy, regulatory, management, and research tool because it captures a key driver of climate (radiative forcing) with minimal uncertainty. The global temperature change potential (GTP) is conceptually more useful as a metric of ecosystem-climate feedbacks because it computes global temperature as the product of radiative forcing and a climate sensitivity parameter (Shine and others 2005). However, for a given change in greenhouse gas emissions, there is far more certainty about the processes that govern radiative forcing than the processes that govern climate sensitivity. Thus, GTP calculations have the potential to produce a wider range of outcomes than GWP depending on model structure and assumptions, making GTP more value-laden, less certain, and perhaps less appealing as an accounting and policy tool. A number of other metrics such as the climate change impact potential (Kirschbaum 2014), cost-effective temperature potential (Johansson 2012), global cost potential (Manne and Richels 2001), and global damage potential (Kandlikar 1995) go well beyond GTP by modeling the impacts of greenhouse gas emissions on environmental, economic, and social outcomes, all of which are of immediate importance to policy makers. The uncertainty of measurements and metrics increases as one moves from considering emissions (reasonably well constrained) to quantifying radiative forcing (minimal uncertainty) to calculating temperature change (greater uncertainty) to forecasting actual impacts on social and economic systems (highest uncertainty) (Fuglestvedt and others 2003; Prather and others 2009). In other words, the level of uncertainty increases as the metric encompasses processes with increasing relevance to ecological, social, or economic outcomes. To date, ecosystem ecologists have not debated the balance between certainty, relevance, and time frame that is most appropriate for advancing science as opposed to policy.

The effect any ecosystem has on global radiative forcing (and by extension, climate) will be the balance between cooling due to long-term $\mathrm{C}$ sequestration plus any $\mathrm{CH}_{4}$ or $\mathrm{N}_{2} \mathrm{O}$ uptake that has taken place over the lifetime of the site, and the warming due to greenhouse gas emissions over recent decades (for $\mathrm{CH}_{4}$ ) to centuries (for $\mathrm{N}_{2} \mathrm{O}$ ). Because of varying time frames over which ecosystems affect climate, using a defined period metric such as SGWP, GWP, GTP, or one of the others mentioned above can yield misleading conclusions about the long-term climatic role of ecosystems. Indeed, a site that has a warming effect on climate over a defined 100 (or 20, or 500)-year period may actually have a net cooling effect when greenhouse gas uptake and emission are integrated over the lifetime of the system (Frolking and Roulet 2007). Depending on the ratio of greenhouse gas uptake to emissions, it can take decades to thousands of years before cumulative radiative forcing from a site switches from positive (net warming) to negative (net cooling), a point known as the radiative forcing switchover time (Frolking and others 2006; Neubauer 2014). When the ratio of $\mathrm{CO}_{2}$ sequestration to either $\mathrm{CH}_{4}$ or $\mathrm{N}_{2} \mathrm{O}$ emissions is the same as the SGWP, then the switchover time will be the time frame over which the SGWP was calculated. For example, an ecosystem that sequesters $45 \mathrm{~kg} \mathrm{CO}$ per $\mathrm{kg} \mathrm{CH} \mathrm{CH}_{4}$ emitted (that is, a ratio equivalent to the 100-year SGWP for $\mathrm{CH}_{4}$, Table 1) has a cumulative radiative forcing switchover time of 100 years.

Unlike metrics such as the GWP, SGWP, or SGCP, the modeling of switchover times does not require one to use a fixed time frame (for example, 20 or 100 years). Using this approach on the previously discussed Poffenbarger and others (2011) $\mathrm{CH}_{4}$ emission dataset (assuming a conservative carbon accumulation rate of $44 \mathrm{~g} \mathrm{C} \mathrm{m}^{-2} \mathrm{y}^{-1}$, which is the 5 th percentile of the Chmura and others 2003 dataset), we calculate that 9 of 10 marshes with salinity at least 18 had an immediate and a persistent net cooling effect (switchover time $=0$ years), whereas one site had a switchover time of 195 years. In contrast, the switchover times for tidal freshwater and brackish marshes (salinity $<18$ ) were considerably higher (median $=663$ years; 5 th-95th percentile range $=$ 26-17,000 years). Modeling switchover times also offers flexibility, as it is not necessary to assume a constant flux over time (an implicit assumption behind SGWP and SGCP values). Instead, one could, for example, take into account temporal changes in carbon sequestration as a forest matures (Gough and others 2008) or in methanogenesis as a created wetland develops (Liikanen and others 2006; Cornell and others 2007). This type of modeling approach, therefore, has high potential to provide valuable scientific insights into the climatic role of ecosystems and is an example of a new approach that the ecological community could adopt independently of the needs of policy makers.

\section{ConCluding Remarks}

Although the GWP has been in use for decades, the climate community is still developing new metrics (for example, Kirschbaum 2014) and discussing which metrics are most appropriate for addressing 
and mitigating the various environmental, social, and economic impacts of climate change (Myhre and others 2013a). There is no single "perfect" metric. However, the analyses and arguments presented herein indicate that the use of GWPs for assessing the climatic impacts of ecosystems is fundamentally untenable. We suggest that use of the SGWP and SGCP is a more appropriate way of understanding the greenhouse gas source/sink status of ecosystems, but conclude that these metrics share many of the shortcomings of the GWP. We propose that the ecological research community should adopt a dynamic modeling approach that provides insights into the lifetime climatic role of an ecosystem (for example, by calculating switchover times). From a research perspective, we question whether the ecosystem science community should be using metrics that were developed for policy applications when other approaches (modeling) are likely to provide more relevant scientific insights. Ultimately, we hope that this article will motivate the ecological community to consider whether GWPs are being used correctly and to begin a larger discussion about the most appropriate way(s) of assessing and quantifying the role of ecosystems as regulators of global climate.

\section{OPEN ACCESS}

This article is distributed under the terms of the Creative Commons Attribution 4.0 International License (http://creativecommons.org/licenses/by/ 4.0/), which permits unrestricted use, distribution, and reproduction in any medium, provided you give appropriate credit to the original author(s) and the source, provide a link to the Creative Commons license, and indicate if changes were made.

\section{REFERENCES}

Bartlett KB, Bartlett DS, Harriss RC, Sebacher DI. 1987. Methane emissions along a salt marsh salinity gradient. Biogeochemistry 4:183-202.

Berntsen T, Fuglestvedt J, Joshi M, Shine KP, Stuber N, Ponater M, Sausen R, Hauglustaine DA, Li L. 2005. Response of climate to regional emissions of ozone precursors: sensitivities and warming potentials. Tellus B 57B:283-304. doi:10.1111/j. 1600-0889.2005.00152.x.

Bridgham SD, Megonigal JP, Keller JK, Bliss NB, Trettin CC. 2006. The carbon balance of North American wetlands. Wetlands 26:889-916.

Canadell JG, Schulze ED. 2014. Global potential of biospheric carbon management for climate mitigation. Nat Commun 5:5282. doi:10.1038/ncomms6282.

Chapuis-Lardy L, Wrage N, Metay A, Chotte J-L, Bernoux M. 2007. Soils, a sink for $\mathrm{N}_{2} \mathrm{O}$ ? A review. Glob Change Biol 13:117. doi:10.1111/j.1365-2486.2006.01280.x.
Chmura GL, Anisfeld SC, Cahoon DR, Lynch JC. 2003. Global carbon sequestration in tidal, saline wetland soils. Global Biogeochemical Cycles 17:Article 1111.

Ciais P, Sabine CL, Bala G, Bopp L, Brovkin V, Canadell JG, Chhabra A, Defries R, Galloway J, Heimann M, Jones C, Le Quéré C, Myneni RB, Piao S, Thornton P. 2013. Carbon and other biogeochemical cycles. In: Stocker TF, Qin D, Plattner GK, Tignor M, Allen SK, Boschung J, Nauels A, Xia Y, Bex V, Midgley PM, Eds. Climate change 2013: The physical science basis. Contribution of Working Group I to the Fifth Assessment Report of the Intergovernmental Panel on Climate Change. Cambridge: Cambridge University Press, p. 465-570.

Cornell JA, Craft CB, Megonigal JP. 2007. Ecosystem gas exchange across a created salt marsh chronosequence. Wetlands 27:240-50

Couwenberg J, Thiele A, Tanneberger F, Augustin J, Bärisch S, Dubovik D, Liashchynskaya N, Michaelis D, Minke M, Skuratovich A, Joosten H. 2011. Assessing greenhouse gas emissions from peatlands using vegetation as a proxy. Hydrobiologia 674:67-89. doi:10.1007/s10750-011-0729-x.

Deshpande B, Hunsaker L, Vayssières M, Lutter K, Eslinger K, Scott K, Huang A. 2014. California's 2000-2012 greenhouse gas emissions: Technical support document. Accessed 06 January 2015 from http://www.arb.ca.gov/cc/inventory/doc/ doc.htm.

Dutaur L, Verchot LV. 2007. A global inventory of the soil $\mathrm{CH}_{4}$ sink. Global Biogeochemical Cycles 21:GB4013. doi:10.1029/ 2006 GB002734.

Frolking S, Roulet NT. 2007. Holocene radiative forcing impact of northern peatland carbon accumulation and methane emissions. Glob Change Biol 13:1079-88. doi:10.1111/j.13652486.2007.01339.x.

Frolking S, Roulet N, Fuglestvedt J. 2006. How northern peatlands influence the Earth's radiative budget: Sustained methane emission versus sustained carbon sequestration. J Geophys Res 111:G01008. doi:10.1029/2005JG000091.

Fuglestvedt JS, Isaksen ISA, Wang W-C. 1996. Estimates of indirect global warming potentials for $\mathrm{CH}_{4}, \mathrm{CO}$ and $\mathrm{NO}_{\mathrm{X}}$. Clim Change 34:405-37. doi:10.1007/BF00139300.

Fuglestvedt JS, Berntsen TK, Godal O, Sausen R, Shine KP, Skodvin T. 2003. Metrics of climate change: Assessing radiative forcing and emission indices. Clim Change 58:267-331. doi:10.1023/A:1023905326842.

GCP (Global Carbon Project). 2013. Methane budget and trends 2013. Released 23 September 2013, accessed 21 February 2015 from http://www.globalcarbonproject.org/methanebudget.

Gorham E. 1991. Northern peatlands: Role in the carbon cycle and probable responses to climatic warming. Ecol Appl 1:18295.

Gough CM, Vogel CS, Schmid HP, Curtis PS. 2008. Controls on annual forest carbon storage: Lessons from the past and predictions for the future. Bioscience 58:609-22. doi:10.1641/ B580708.

Hakkenberg R, Churkina G, Rodeghiero M, Börner A, Steinhof A, Cescatti A. 2008. Temperature sensitivity of the turnover times of soil organic matter in forests. Ecol Appl 18:119-31.

Harvey LDD. 1993. A guide to global warming potentials (GWPs). Energy Policy 21:24-34. doi:10.1016/03014215(93)90205-T.

Johansson DJA. 2012. Economics- and physical-based metrics for comparing greenhouse gases. Clim Change 110:123-41. doi:10.1007/s10584-011-0072-2. 
Johnson C, Derwent R. 1996. Relative radiative forcing consequences of global emissions of hydrocarbons, carbon monoxide and $\mathrm{NO}_{\mathrm{x}}$ from human activities estimated with a zonally-averaged two-dimensional model. Clim Change 34:439-62.

Joos F, Roth R, Fuglestvedt JS, Peters GP, Enting IG, von Bloh W, Brovkin V, Burke EJ, Eby M, Edwards NR, Friedrich T, Frölicher TL, Halloran PR, Holden PB, Jones C, Kleinen T, Mackenzie FT, Matsumoto K, Meinshausen M, Plattner G-K, Reisinger A, Segschneider J, Shaffer G, Steinacher M, Strassmann K, Tanaka K, Timmermann A, Weaver AJ. 2013. Carbon dioxide and climate impulse response functions for the computation of greenhouse gas metrics: A multi-model analysis. Atmos Chem Phys 13:2793-825. doi:10.5194/acp-132793-2013.

Kandlikar M. 1995. The relative role of trace gas emissions in greenhouse abatement policies. Energy Policy 23:879-83. doi:10.1016/0301-4215(95)00108-U.

Kirschbaum MUF. 2014. Climate-change impact potentials as an alternative to global warming potentials. Environ Res Lett 9:034014. doi:10.1088/1748-9326/9/3/034014.

Le Mer J, Roger P. 2001. Production, oxidation, emission and consumption of methane by soils: a review. Eur J Soil Biol 37:25-50.

Liikanen A, Huttunen JT, Karjalainen SM, Heikkinen K, Väisänen TS, Nykänen H, Martikainen PJ. 2006. Temporal and seasonal changes in greenhouse gas emissions from a constructed wetland purifying peat mining runoff waters. Ecol Eng 26:241-51. doi:10.1016/j.ecoleng.2005.10.005.

Manne AS, Richels RG. 2001. An alternative approach to establishing trade-offs among greenhouse gases. Nature 371:675-7. doi:10.1038/35070541.

Moseman-Valtierra S. 2012. Reconsidering the climatic role of marshes: Are they sinks or sources of greenhouse gases? In: Abreu DC, de Borbón SL, Eds. Marshes: ecology, management and conservation. Hauppauge: Nova Scientific Publishers. p 1-48.

Myhre G, Shindell D, Bréon F-M, Collins W, Fuglestvedt JS, Huang J, Koch D, Lamarque J-F, Lee D, Mendoza B, Nakajima T, Robock A, Stephens G, Takemura T, Zhang H. 2013a. Anthropogenic and natural radiative forcing. In: Stocker TF, Qin D, Plattner G-K, Tignor M, Allen SK, Boschung J, Nauels A, Xia Y, Bex V, Midgley PM, editors. Climate change 2013: The physical science basis. Contribution of Working Group I to the Fifth Assessment Report of the Intergovernmental Panel on Climate Change. Cambridge, UK: Cambridge University Press. p. 659-740.

Myhre G, Shindell D, Bréon F-M, Collins W, Fuglestvedt JS, Huang J, Koch D, Lamarque J-F, Lee D, Mendoza B, Nakajima T, Robock A, Stephens G, Takemura T, Zhang H. 2013b. Anthropogenic and natural radiative forcing, Supplementary Material. In: Stocker TF, Qin D, Plattner G-K, Tignor M, Allen SK, Boschung J, Nauels A, Xia Y, Bex V, Midgley PM, Eds. Climate change 2013: The physical science basis. Contribution of Working Group I to the Fifth Assessment Report of the Intergovernmental Panel on Climate Change. Available from www.climatechange2013.org and www.ipcc.ch. p. 8SMl-44.

Neubauer SC. 2014. On the challenges of modeling the net radiative forcing of wetlands: Reconsidering Mitsch and others (2013). Landscape Ecol 29:571-7. doi:10.1007/s10980-0149986-1.

O'Neill BC. 2000. The jury is still out on Global Warming Potentials. Clim Change 44:427-43. doi:10.1023/A:1005582929198.
Pierrehumbert RT. 2014. Short-lived climate pollution. Annu Rev Earth Planet Sci 42:341-79. doi:10.1146/annurev-earth060313-054843.

Poffenbarger HJ, Needelman BA, Megonigal JP. 2011. Salinity influence on methane emissions from tidal marshes. Wetlands 31:831-42. doi:10.1007/s13157-011-0197-0.

Prather MJ, Penner JE, Fuglestvedt JS, Kurosawa A, Lowe JA, Höhne N, Jain AK, Andronova N, Pinguelli L, Pires de Campos C, Raper SCB, Skeie RB, Stott PA, van Aardenne J, Wagner F. 2009. Tracking uncertainties in the causal chain from human activities to climate. Geophys Res Lett 36:L05707. doi:10. 1029/2008GL036474.

Robertson GP, Paul EA, Harwood RR. 2000. Greenhouse gases in intensive agriculture: Contributions of individual gases to the radiative forcing of the atmosphere. Science 289:1922-5. doi:10.1126/science.289.5486.1922.

Rodhe H. 1990. A comparison of the contribution of various gases to the greenhouse effect. Science 248:1217-19. doi:10. $1126 /$ science.248.4960.1217.

Serrano-Silva N, Sarria-Guzmán Y, Dendooven L, Luna-Guido M. 2014. Methanogenesis and methanotrophy in soil: A review. Pedosphere 24:291-307. doi:10.1016/S1002-0160(14) 60016-3.

Shine KP. 2009. The global warming potential-the need for an interdisciplinary retrial. Clim Change 96:467-72. doi:10.1007/ s10584-009-9647-6.

Shine KP, Derwent RG, Wuebbles DJ, Morcrette J-J. 1990. Radiative forcing of climate. In: Houghton JT, Jenkins GJ, Ephraums JJ, Eds. Climate change: The IPCC scientific assessment. Working Group I. Cambridge, UK: Cambridge University Press. p. 41-68.

Shine KP, Fuglestvedt JS, Hailemariam K, Stuber N. 2005. Alternatives to the global warming potential for comparing climate impacts of emissions of greenhouse gases. Clim Change 68:281-302. doi:10.1007/s10584-005-1146-9.

Shrestha R, Lal R, Penrose C. 2009. Greenhouse gas emissions and global warming potential of reclaimed forest and grassland Soils. J Environ Qual 38:426-37. doi:10.2134/jeq2008. 0283.

Siegenthaler U, Sarmiento J. 1993. Atmospheric carbon dioxide and the ocean. Nature 365:119-25.

Smith S, Wigley T. 2000. Global warming potentials: 2. Accuracy. Clim Change 44:459-69. doi:10.1023/A:100553701 4987.

Syakila A, Kroeze C. 2011 . The global nitrous oxide budget revisited. Greenhouse Gas Meas Manage 1:17-26. doi:10.3763/ ghgmm.2010.0007.

Torn MS, Trumbore SE, Chadwick OA, Vitousek PM, Hendricks DM. 1997. Mineral control of soil organic carbon storage and turnover. Nature 389:170-3. doi:10.1038/38260.

UNFCCC (United Nations Framework Convention on Climate Change). 2014. Report of the Conference of the Parties on its nineteenth session, held in Warsaw from 11 to 23 November 2013. Decision 14/CP.19 Modalities for measuring, reporting, and verifying. Accessed 06 January 2015 from http://unfccc. int/redd

van Groenigen KJ, Osenberg CW, Hungate BA. 2011. Increased soil emissions of potent greenhouse gases under increased atmospheric $\mathrm{CO}_{2}$. Nature 475:214-16. doi:10.1038/nature 10176. 
VCS (Verified Carbon Standard). 2013. VCS standard: Requirements document, v3.4. Accessed 06 January 2015 from http:// www.v-c-s.org/program-documents

Walker JCG. 1991. Biogeochemical cycles of carbon on a hierarchy of time scales. In: Oremland RS, Ed. Biogeochemistry of global change. New York: Chapman and Hall. p 3-28.
Weston NB, Neubauer SC, Velinsky DJ, Vile MA. 2014. Net ecosystem carbon exchange and the greenhouse gas balance of tidal marshes along an estuarine salinity gradient. Biogeochemistry 120:163-89. doi:10.1007/s10533-014-9989-7.

Whiting GJ, Chanton JP. 2001. Greenhouse carbon balance of wetlands: Methane emission versus carbon sequestration. Tellus B 53:521-8. doi:10.1034/j.1600-0889.2001.530501.x. 